\title{
Processing of Political Contents of Mass Media: An Analysis under the Elaboration
}

\section{Likelihood Model of Persuasion}

* Dr. Imran Muslim, Assistant Professor (Corresponding Author)

** Dr. Faiza Latif, Assistant Professor

*** Dr. Muhammad Shabbir Sarwar, Assistant Professor

\begin{abstract}
This study deals with the processing of political information disseminated through mass media. "Elaboration Likelihood Model" of persuasion was used as a framework for this study. A list comprising of general sentences used in favor and against the major political parties of Pakistan was used as "central" and "peripheral" cues. A combination of stratified and multistage cluster sampling was used to select the youth as respondents for this study. Findings of the study revealed that the Education level of the youth did not prove to be a key factor for using central cues, which are predictors of thoughtful processing of information. More than that a large majority of the youth did not gave much attention to the political contents of mass media, hence by proving that they do not care for the political happenings in the country.
\end{abstract}

Keywords: Elaboration Likelihood Model, Information Processing, Mass media, Youth.

\section{Introduction}

Persuasion is considered to be the most progressive technique to change the attitude of others. "It is possible that a persuasive person can succumb to the will of the world's population through the media" (Cartwright, 1949).

Attitude change techniques are widely used in politics. Democracy is considered as the most culturally rich state system, which always needs convincing communication and support to earn the favor of people.

Persuasion is a central chunk of politics and an essential part of striving and exercising supremacy of this system. Political persuasion is the procedure in which the communicator attempts to use the information to convince the audience to change their attitude or exercising and facing political issues in a free atmosphere (Pfau et al., 2002).

As the field of political communication develops, studies of the process and effects of persuasive political communication also continue to evolve. Political persuasion unifies ideology in a perspective in which most people have seemingly incompatible characteristics, but have strong feelings about the problem and rarely consider the context in which those problems arise.

Historically, prospects and consequences concomitant with political socialization were simply "voting". But in the present situation, we must take into account many other happenings, such as involvement in political affairs, political information, participation in the radical debate, and voting, evidently based on ideology. While considering these findings, the character of organizations and the media (especially "new media") cannot be overlooked (Coppock, 2016).

"New media" have also made changes to sensitize political experts to study the effects of this new socialization instrument (Fautsch, 2007).

Chafee gave an understanding of media consumption for political sense. He explored that a close relationship prevails between political participation and the growing use of the media to obtain information on national and international procedures (Huber, G.A. and Arceneaux, K., 2007).

\footnotetext{
* Department of Mass Communication Government College University Faisalabad, Punjab, Pakistan Email: imranmuslim@gcuf.edu.pk

** Lahore College for Women University Punjab, Pakistan Email: faiza.latif@lcwu.edu.pk

*** Institute of Communication Studies University of the Punjab, Pakistan Email: Shabbier.ics@pu.edu.pk
} 


\section{Considerable Methods for Building Trust}

The first step for the media is to get the attention of the public, and then they try to gain the faith of users. (Severin, Tankard, 2000). To achieve this goal, the media exercise different types of techniques. For example, "plain folk's method" gains assurance and reliability by giving gestures that the characters of media programs are very much similar to the audience. By showing that they are ordinary people, they insist to be a fragment of the atmosphere that ordinary people experience.

"Sentimentality" is a continuation of the usual folk tricks. It creates a perception of a contender in an intimate relationship full of affection and satisfaction. Examples of this approach include the image of political candidates and their families, everyone seems happy and friendly. Talking about the kindness, loyalty, and ease of candidates can also affect mood.

"Charisma" is a characteristic that attracts citizens to interact with others. It is the perfect combination of elegance, strength, sincerity, and charm. Sociologist Max Weber was the pioneer to propose the concept of the Charisma mechanism, a century ago (DeBono, Harnish, 1988).

\section{Political Apathy}

Political dependability has often been a problem for Pakistan. There is always a rift among people in the party and the army. Politicians have accused the military of not allowing smooth political procedures, and the suspension of martial law has also disrupted the path to political maturity.

On the other hand, the military believes that the poor management of politicians and the terrible living conditions of the people are forcing them to seize power. They consider themselves to be the actual liberators of the country.

Irrespective of the real benefits of this discussion for the people of Pakistan, the fact is that all stakeholders in Pakistan agree that young people might be provided with consideration and attention because they make the major proportion of the population of Pakistan. Besides, due to the increased literacy rate and the availability of multichannel cable television, young people are expected to be more knowledgeable and more socialized.

The phenomenon of apathy of young people prevails almost all over the world. In less developed countries such as Pakistan, Bangladesh, Nepal, Afghanistan, and more or less all African states, the condition is even more severe. Firstly, people lack interest in politics. Secondly, if young people participate in such activities to some extent, they will not behave like mature and educated people. In a country like Pakistan, an increase in literacy rates does not ensure political maturity. The correlation between the educational level of Pakistani youth and political socialization is low (Muslim. I, 2012).

To analyze people's thinking, Petty and Cacioppo developed a special method to develop an information processing model called a probabilistic model (ELM).

\section{Elaboration Likelihood Model}

Elaboration Likelihood Model (ELM) is a two-way process. This model facilitates analyzing how attitudes of people are formed. The theory suggests an "elaboration range" that determines the degree of processing and evaluation parameters (Seiter, Robert H. Gass, 2010).

The theoretical framework and the proposed model explain two diverse dispensation modes. The foremost is called the central route and the other one is called the peripheral route. The central route encourages the public to use their analytical skills so that it may prevail for a lengthier time while supporting high-level development. The central route involves an in-depth evaluation of persuasive messages (such as voice, advertising, etc.) to determine the quality of the argument. In this case, a person's unique reaction to a message determines the outcome of this convincing communication. If someone uses a central route to process information and finds that the information is reliable, thoughtful, and motivating, then even if the information conflicts with the recipient's previous opinions on this issue, it is usually considered beneficial information. Therefore, if a good feeling is generated during the development process, then the knowledge will be acknowledged; whereas in other cases, the information is probable to be rejected (Petty \& Cacioppo, 1979).

If the information is to be analyzed along a central route, the required personals must be capable and motivated to proceed as mentioned. In case the recipient wants to use the central mode for processing information, it should be related to this individual. In contrast, the peripheral path does not involve the development of information via intensive reasoning processing and don't attempt to test the merits of the arguments presented. These programs usually emphasize on the peripheral characteristics of the information, for instance, the reputation of the source, the excellence of the 
demonstration, the pleasing outlook of the presenter, or the striking slogan in the communication process (Petty \& Cacioppo, 1979).

Peripheral routing is also utilized for messages that have no logical appeals or contain week parameters. This can be seen as a shortcut for humans to avoid trying to make effort (Petty, Richard E.; Cacioppo, John T, 1986).

\section{Selection of Route}

The two most effective factors in choosing the route of a persuasive situation are ability (ability to process messages) and motivation (a high desire to pay attention to messages) ((Petty and Cacioppo, 1979 and Petty, Cacioppo, Wells and Brock, 1986).

The selection of route depends on the intensity of the need. Both inspiration and ability determine the development process. Motivational components contain the "personal importance" of the message and the topic of "need to know" people. The ability to process information depends on the degree of socialization, education, peer group, ability to withstand exterior pressure, and selfassurance (Petty \& Cacioppo, 1979).

\section{Rationale of the Study}

The Elaboration Likelihood model shows that the central route is related to effective cognitive performance. For intensive cognitive processes, rational analysis of knowledge, evidence, and understanding is a basic requirement.

As much as political knowledge is concerned, for most people, exposure to information is huge and comfortable. Voters, particularly young ones, can watch TV, consume social media and read newspapers online. They usually also have a group of vocal colleagues. Besides, it is expected that the Punjab government's educational opportunities and active campaigns and literacy rates will increase. Therefore, it can be considered that young people in Punjab are more alert, knowledgeable, and willing to process information logically and intelligently.

However, people still voted to elect the government, and a few days later, they began to feel embarrassed of their choice. Under this, it is imperative to investigate the factors that influence young people's thinking when dealing with political information. This research can help reveal the comparative effects of variables such as education level, demographic differences, party membership, and other associated factors.

\section{Objectives of the Study}

Investigators have tried to be precise and to the point towards the topic of this study. Clear and brief objectives have been tailored so that this study may be productive and unambiguous for the society.

The following are the key objectives, set by the researcher before conducting this study.

- To cognize the "thought process" of youth, about political affairs.

- To investigate the impression of education level on political decisions made youth.

- To analyze the central and peripheral cues practiced by the youth in the procedure of persuasion.

\section{Research Questions}

To examine the youth for processing of political contents by them, the following research questions have been devised.

1. Do youth take the political contents of mass media as a serious phenomenon and consider them important enough to spare time for their careful processing?

2. What is the relationship between the level of education and choice of cues, while processing political contents?

3. How education and choice of a political party are interlinked?

\section{Research Method}

This research requires research subjects to provide comprehensive feedback on their current political views, methods of accessing political information, and making decisions on such issues.

An inclusive questionnaire was tailored as a tool for data collection. The questionnaire comprised of two portions. The foremost part focuses on trends in media consumption, demographic data, and trends in the political contribution of research subjects, while the second part of the questionnaire contains a list of favorite political parties and two other warring parties. The respondents mainly mentioned the three main political parties in the Punjab ("Pakistan Muslim League", "Pakistan Tehreek-i-Insaf" and Pakistan People's Party). Some of the smaller parties, such 
as Pakistani Muslim League Q, Pakistan Awami Tehrik, and Jamat-e- Islami, are popular or disliked by a small number of people and are therefore classified as "others".

These indices are selected from general public opinion about the pros and cons of political parties and are tracked during the testing process to complete the questionnaire.

\section{Population size}

The Punjab province was chosen as the population for this survey research. Punjab Province is the largest province in Pakistan and is made up of a wide variety of populations. People's habits, characteristics, and lifestyles vary.

In terms of political affairs, the Punjab have a key part in national politics. Generally, the political party that leads the elections in the province also gets the majority in the central government. This is the reason that people of Punjab, especially young people, have the primary responsibility for making wise decisions and making decisions when voting. A political party uses all traditional methods in its political activities, including media campaigns, activation, unapproved statements, and emotional appeals. Therefore, this study seeks to explain how political parties govern political communication through the media.

\section{Sampling Technique}

Taking into account changes in lifestyle, infrastructure level, and availability of communications, the entire population was divided into four strata. Each layer was processed using a "multistage cluster sampling technique" to select the desired population. The researchers used "alternative sampling" methods when contacting randomly selected respondents. Below is an example of the distribution of all four layers and their subsequent subdivisions.

\begin{tabular}{ccccccc}
\hline & \multicolumn{5}{c}{ Sampling Grid } & \\
\hline $\begin{array}{c}\text { Metropolitan "Faisalabad" } \\
\text { (Stratum 1) }\end{array}$ & Gulistan Colony & Raza abad & Abdulla Pur & Sarfraz Colony & \\
Sample Size & 69 & 68 & 67 & 69 & 273 \\
Major City (Stratum 2) & Sial Kot & Jhang & Rawalpindi & Raheem Yar Khan & \\
Sample Size & 61 & 61 & 61 & 60 & 243 \\
Small City/Town (Stratum 3) & Chicha watni & T.T. Singh & M.B.Din & Khan Pur & \\
Sample Size & 60 & 62 & 61 & 62 & 245 \\
& Chak No 115 & Chak No. & Bhogi Chak & Chak No 151 & \\
Villages & GB Tandlian & 107 ML & UC & Dunya Pur, & \\
(Stratum 4) & Wala & Fateh Pur, & “Adrana” & Mailsee & \\
& Layya & Jehlam & 69 & 273 \\
Sample Size & 68 & 68 & 68 & $\mathbf{2 5 9}$ & $\mathbf{1 0 3 4}$ \\
\hline Grand Total & $\mathbf{2 5 8}$ & $\mathbf{2 5 9}$ & $\mathbf{2 5 8}$ & & \\
\hline
\end{tabular}

\section{Table 1: $\quad$ Sampling Grid}

\section{Refinement of the Questionnaire}

More than 100 people, who were selected on a "convenience bases", were requested to mention, how, do they consider the major political parties. Remarks uttered in favor or against were registered and more repeatedly used remarks were chosen to be used as peripheral or central cues in the questionnaire. To be accurate "four" sentences in favor and "three" against each party have opted.

\section{Operation Definition}

- According to the "National Bureau of Statistics of Pakistan", the city with inhabitants over "one million" has acquired the eminence of a metropolitan. In this study, metropolitans are the first stratum.

- Cities with a population of 2,000.00 to 5, 00000 are considered large cities and are denoted as stratum Number 2.

- A city with a population in the range of $1,000,000-2,000,000$ is considered a small city and is designated as the third stratum

- A group of houses with specific names or numbers included in some trade union councils that are smaller than cities are considered villages and are called the fourth stratum.

- $\quad$ Every resident of Punjab from 18 to 36 years old is defined as youth.

\section{Results and Discussion}

The first part of the questionnaire for this study comprised of personal profile of the respondents and their pattern of media consumption for political contents. Figure 1 presents the level of political interest of the respondents as per their exposure to political information through mass media. 
Fig. 1.1

Level of political Interest of youth of Punjab Province
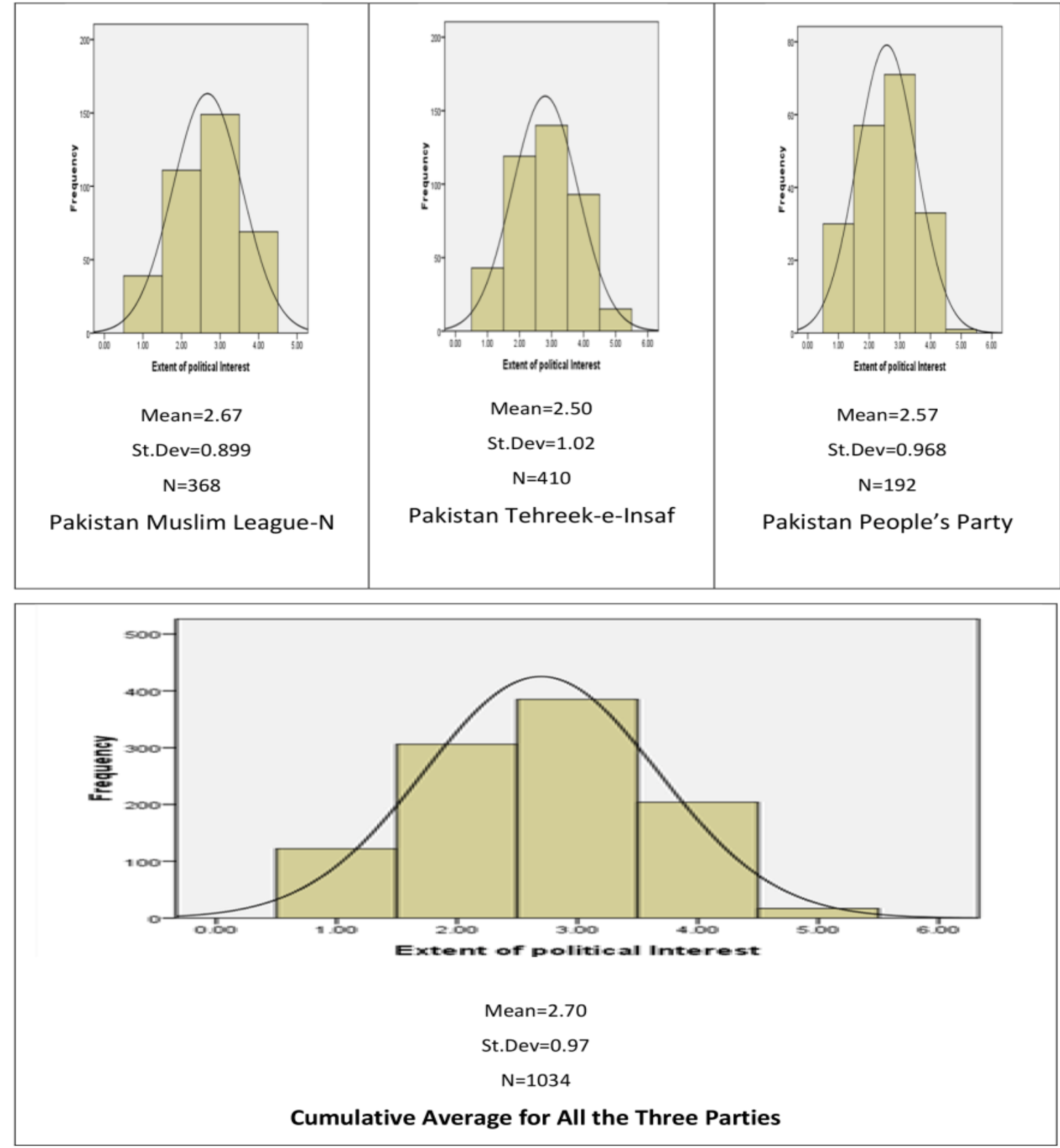

Providing respondents with a Likert scale (including 5 options, from "most interested" to "not paying attention") to assess respondents' political interests.

The answer is represented by the frequency table and the histogram. $37.2 \%$ of study participants said their political interests were "at the right level." Therefore, they seem to be satisfied with their political interests. $29.6 \%$ of members acknowledged that they had political interests and a low affinity. $11.8 \%$ are not interested. The overall responses of 1,034 respondents can be aggregated, including an average of 2.70 .

This pattern of political interest was also transmitted to the followers of the other main political parties investigated in this research paper.

It is important to note that when using the Likert scale, the "mode" is considered the best choice, but in this case, the average is calculated to obtain a comparison chart for all three aspects. Histogram data show that for PML-N, PTI and PPP, the average values of political interest are "2.67", "2.80" and "2.57", respectively. Therefore, from the above values it can be understood that, compared 
to PML-N and PPP, ITP supporters show a greater interest in the political process. This variation in the degree of political interest maybe since the ITP is a relatively dynamic party and is in the early stages of raising awareness among its young people through dynamic contributions in political press and TV talk shows.

The questionnaire contains a list of central and peripheral cues (commonly used voting suggestions, i.e. why they like their Favorite party and oppose their opposition party or leader), so it was easy to determine the choice of route when it comes to information from their Favorite or disliked parties. The table below shows the relationship between the choice of route and the educational level of the respondents.

\begin{tabular}{|c|c|c|c|c|c|c|}
\hline \multirow{2}{*}{ Education Level } & \multirow{2}{*}{$\begin{array}{l} \\
\text { Pearson } \\
\text { Correlation }\end{array}$} & \multicolumn{2}{|c|}{$\begin{array}{c}\text { Education Main Reason To } \\
\text { Level } \\
\text { admire } \\
\text { Favourite Party }\end{array}$} & \multicolumn{2}{|c|}{$\begin{array}{c}\text { Main Reason To } \\
\text { Dislike Opponent } \\
\text { Party No } 1\end{array}$} & $\begin{array}{l}\text { Main Reason To Hate } \\
\text { Opponent Party No } 2\end{array}$ \\
\hline & & 1 & -.014 & -.02 & & -.004 \\
\hline \multirow{5}{*}{$\begin{array}{l}\text { Main Reason To } \\
\text { admire Favorite Party }\end{array}$} & Sig. (2-tailed) & & .647 & .36 & & .885 \\
\hline & $\mathrm{N}$ & 1034 & 1034 & 103 & & 1034 \\
\hline & $\begin{array}{l}\text { Pearson } \\
\text { Correlation }\end{array}$ & -.014 & 1 & .672 & & $.564^{* *}$ \\
\hline & Sig. (2-tailed) & .647 & & .00 & & .000 \\
\hline & $\mathrm{N}$ & 1034 & 1034 & 103 & & 1034 \\
\hline \multirow{3}{*}{$\begin{array}{c}\text { Main Reason To } \\
\text { Dislike Opponent Party } \\
\text { No } 1\end{array}$} & $\begin{array}{l}\text { Pearson } \\
\text { Correlation }\end{array}$ & -.028 & $.672^{* *}$ & 1 & & $.788^{* *}$ \\
\hline & Sig. (2-tailed) & .369 & .000 & & & .000 \\
\hline & $\mathrm{N}$ & 1034 & 1034 & 103 & & 1034 \\
\hline \multirow[t]{3}{*}{$\begin{array}{l}\text { Main Reason To Hate } \\
\text { Opponent Party No } 2\end{array}$} & $\begin{array}{l}\text { Pearson } \\
\text { Correlation }\end{array}$ & -.004 & $.564^{* *}$ & .788 & & 1 \\
\hline & Sig. (2-tailed) & .885 & .000 & .00 & & \\
\hline & $\mathrm{N}$ & 1034 & 1034 & 103 & & 1034 \\
\hline \multicolumn{7}{|c|}{ Education Level and selection of cue for liking or disliking a Political party } \\
\hline \multicolumn{7}{|c|}{ Education Level } \\
\hline & Uneducated 1 & To 5 Years & $\begin{array}{l}6 \text { To } 10 \\
\text { Years }\end{array}$ & $\begin{array}{l}\text { ntermediate } \\
\text { (12 Years) }\end{array}$ & $\begin{array}{l}\text { Graduation } \\
\text { (14 Years) }\end{array}$ & $\begin{array}{l}\text { Masters } \\
\text { (16 years) or } \\
\text { Higher }\end{array}$ \\
\hline & \multicolumn{3}{|c|}{ Computation Computation Computation $\mathrm{C}$} & \multicolumn{3}{|c|}{ Computation Computation Computation } \\
\hline $\begin{array}{l}\text { Pakistan Muslim } \\
\text { League }(\mathrm{N})\end{array}$ & 16 & 47 & 52 & 56 & 112 & 85 \\
\hline Pakistan People's Party & 7 & 26 & 30 & 29 & 60 & 40 \\
\hline $\begin{array}{c}\text { Pakistan Tehreek-e- } \\
\text { Insaf }\end{array}$ & 17 & 55 & 60 & 61 & 121 & 96 \\
\hline Others & 4 & 5 & 9 & 12 & 17 & 17 \\
\hline
\end{tabular}

Table 3: $\quad$ Education Level of the respondents and their party selection

Table 3 gives a slight image of the Party affiliation of the youth and their education level. It is noticeable that youth having graduation or above degree are the least in number to have affiliation with the Pakistan people's party, in contrast with the other two parties.

\begin{tabular}{cccc}
\hline & & Level of education & Favorite Political Party \\
\hline \multirow{3}{*}{ Level of education } & Pearson Correlation & 1 & 0.003 \\
& Sig. (2-tailed) & & 0.915 \\
& N & 1034 & 1034 \\
& Pearson Correlation & .003 & 1 \\
Favorite Political Party & Sig. (2-tailed) & .915 & 1034 \\
& $\mathrm{~N}$ & 1034 & 1034 \\
\hline
\end{tabular}




\section{Table 4: $\quad$ Relationship between choice of political party and Education}

The choice of political parties by respondents represents an odd pattern that has nothing to do with educational level.

Table 2 shows that youth, with 16 or more years of education chose a large number of peripheral cues, including "reciprocity", "expert source" and "social pressure". If we compare this to those having elementary school or lower education, they show a similar mix of cue selection.

Pearson correlation test in table "4" once again confirms this point of view. It is evident that education had no positive effect on the central route, but had no or little negative correlation $(\mathrm{P}=-$ $0.014)$.

However, there is a positive relationship between the trends in practicing the central or peripheral cues. For example, if someone likes a "disapproval statement," he or she will use the same cue to dislike it most of the time.

More precisely, for two opposite aspects, the values of liking and disliking attributes are equal to "0.672" and "0.788", respectively. It can be concluded that the level of higher education does not guarantee the priority of the central route.

\section{Conclusion}

It was expected by the researcher that education, being the focused area in the current era, will play a decisive role in decision making by the youth for their political responsibilities. Especially in the presence of a multichannel Television system, providing the latest news and in-depth analysis of political activities in the country and FM radio channels with their availability everywhere, it might have changed the traditional ways of thinking of the new generation but in contrast, education (Formal or Socialization through media) could not help it out.

Youth still was directed by the catchy slogans, Un-approved claims by the political leaders, and Personality following trends to make their political participation in the society.

\section{Bibliography}

Cartwright, D. (1949). Some principles of mass persuasion. Human Relations 2: 253

Coppock, A. E. (2016). Positive, Small, Homogeneous, and Durable: Political Persuasion in Response to Information. Columbia University, Pro-Quest Dissertations Publishing. 10108118.

DeBono, K.G. (1987). "Investigating the social-adjustive and value-expressive functions of attitudes: Implications for persuasion processes". Journal of Personality and Social Psychology 52 (2): 279287.

Fautsch, Leo (2007). "Persuasion". The American Salesman 52 (1): 13-16.

Huber, G.A., \& Arceneaux, K. (2007). Identifying the persuasive effects of presidential advertising. American Journal of Political Science, 51(4): 957-977.

Muslim. I (2012). Role of Cable TV in political socialization of youth. An unpublished thesis of M.Phil Mass Communication. BZU Multan.

Petty, Richard E.; Cacioppo, John T. (1979) "Issue involvement can increase or decrease persuasion by enhancing message-relevant cognitive responses". Journal of Personality and Social Psychology, Vol 37(10), 1915-1926.

Petty \& Cacioppo (1986). "The elaboration likelihood model of persuasion". Advances in Experimental Social Psychology 19 (1): 123-205.

Petty, Richard E.; Cacioppo, John T, (1984). "The effects of involvement on responses to argument quantity and quality: Central and peripheral routes to persuasion”. Journal of Personality and Social Psychology, Vol 46(1), Jan 1984

Petty, Richard E.; Cacioppo, John T. (1984). "Involvement and persuasion: Tradition versus integration". Psychological Bulletin, Vol 107(3)

Pfau, M., Holbert, R.L., Szabo, E.A., \& Kaminski, K. (2002). Issue-advocacy versus candidate advertising: Effects on candidate preferences and democratic process. Journal of Communication, 52(2): 301315.

Seiter, Robert H. Gass, John S. (2010). Persuasion, social influence, and compliance gaining (4th Ed.). Boston: Allyn \& Bacon. p. 33.

Severin. J, Tankard. W (2000). Theories of persuasion. Communication theories, methods, and uses in the mass media. NBF, Islamabad.

Yuqiong, W., Gale L. \& Peter K. (2015). Effects of emotional expressions on persuasion. Social Influence, 10 (4). 